retrograde metamorphism had affected material higher in the crust.

Although it is now known that there was a granitic crust $3.8 \times 10^{9}$ years ago, it is still uncertain as to how extensive it was. Dr C. R. Anhaeusser (University of Witwatersrand) discussed the nature of the crust on which the volcanic and sedimentary rocks of Barberton in South Africa were deposited at least $3.4 \times 10^{9}$ years ago and concluded that it might have been oceanic.

Dr J. F. Wilson (University of Rhodesia) described areas where greenstone belts in Rhodesia are underlain by granitic rocks, but it is possible that these granitic rocks are younger than the Barberton succession, so that it is still uncertain whether southern Africa contains granitic rocks formed before the earliest greenstone belts. These are, however, interesting parallels between the oldest rocks described by Dr Wilson and those from West Greenland known to have formed $3.9 \times 10^{9}$ years ago. In each instance there is a record of repeated intrusion of granitic rock. Several speakers suggested that the make-up of the earliest crust indicated an evolution not through volcanic or sedimentary activity so much as by intrusion, deformation and recrystallization of acid plutonic rock.

Dr C. J. Talbot (University of Dundee) reviewed the possible models which might explain the occurrence of greenstone belts and the adjoining granitic rocks and suggested a mechanism by which small masses of continental crust could be built up by convection. The question of the amount of horizontal movement was brought out in a discussion of the history of Proterozoic fold belts.

Dr R. Mason (R. F. Loxton, Hunting and Associates, Johannesburg) showed striking illustrations of the Limpopo Belt formed probably between 2.8 and $2 \times 10^{9}$ years ago. This belt is remarkable both for the granulite facies metamorphism and for the belts of straightening in which intensively deformed rocks form linear structures within the Limpopo Belt. Dr M. Coward (University of Leeds) suggested that the Limpopo Belt was marked by a transcurrent movement of some $200 \mathrm{~km}$ between the blocks on either side.

In another context $\mathrm{Dr}$ Watson discussed such large linear structures when contrasting the behaviour of granulite facies and lower grade rocks during deformation. She pointed to evidence in Scotland which indicates that granulite facies rocks survived at depth when retrograde metamorphism had occurred higher in the crust and suggested that Wegman's Unterbau, the zone of intense metamorphism, might have a lower boundary. This concept was consistent both with the BridgwaterWindley model of the crust in the early
Precambrian, with a granitic upper part and a granulite-rich lower part. There now seems to be considerable evidence, from studies of heat flow, the distribution of granitic rocks and from structural investigations, that from at least $3.2 \times 10^{9}$ years onwards granulites overlain by granite-rich zone formed an important element in continental crust.

In the final session further examples of Proterozoic deformation were described from Greenland, where basic and ultramafic dyke swarms have provided Drs D. Bridgwater and A. Escher (Geological Survey of Greenland) and Dr J. Watterson (University of Liverpool) with a means of measuring deformation within the Nagssugtoqidian fold belt. This belt contrasts with the Ketilidian of South Greenland formed at roughly the same period, and Dr C. Pulvertaft (Geological Survey of Greenland) joined with these three workers in suggesting how these contrasts reflected long continued differences in crustal behaviour.

Dr P. Hoffman (University of California, Santa Barbara) discussed the Coronation geosyncline in the northwestern Canadian Shield which, though formed more than $1.75 \times 10^{9}$ years ago, he found to be distinguishable only in detail from the Cordilleran or Appalachian geosynclines. This contribution brought the discussion up to the point in time--some $2 \times 10^{9}$ years ago-when Precambrian geological features took on forms familiar through the remainder of geological history.

\section{Patterns of Actin Activity}

X-RAY diffraction techniques can be used to study the structure of muscle, not only in the living resting state, but also in the actively contracting state and in the rigor state. A great deal of interest obviously centres on the actively contracting state and the structural changes that are associated with it. When vertebrate striated muscle is activated there are considerable changes in the X-ray pattern arising from the myosin filament structures, which are attributed to asynchronous movement of the cross-bridges. There are, however, no immediately obvious.changes in the actin pattern.

Recently, there have been more detailed X-ray studies of the contracting and rigor states, and evidence has been accumulating which suggests that there may also be a structural change in the actin filaments associated with activity. In X-ray patterns from contracting vertebrate striated muscle Huxley (Eighth Intern. Cong. Biochem., Interlaken, 1970) observed a diffuse reflexion which was not seen in patterns from the resting muscle, and which he identified as the second layer line of the actin helix. Now, in an article to

\section{CONSERVATION}

\section{Odendual Report}

from a South African Correspondent

SINCE the publication in 1964 of the Report of the Commission of Enquiry into South West African Affairs, 196263 (the Odendaal Commission), conservationists have bemoaned the implication of this report for the wildlife of northern South West Africa, and particularly the Etosha Game Park and the Kaokoveld. Unfortunately there has been little agreement as to either the dangers involved or the possible remedies.

The area concerned is that of the so-called Game Reserve No. 2 which consists of three parts-the Etosha Game Park, a dual-purpose reserve for Africans and wildlife in the northern Kackoveld, and the Kaokoveld Nature Reserve south of this (R. C. Bigalke, Afr. Wild Life, 18, 181; 1964). In terms of the Odendaal Report the dualpurpose reserve is to be deproclaimed, roughly 1,600 square miles are to be excised from the northern and western parts of Etosha Game Park and most of the Kaokoveld Nature Reserve is to be incorporated into a new homeland, Damaraland. A 20-mile strip of the Namib desert, extending from the Kunene river to near Swakopmund, is instead to become a Skeleton Coast reserve. Writing at the request of the Wildlife Protection and Conservation be published in next Wednesday's Nature New Biology (April 12), Vibert, Hazelgrove, Lowy and Poulsen from Aarhus report that in both vertebrate and invertebrate smooth muscles there are changes in the intensities of certain of the actin layer lines when the muscles are activated; in the invertebrate muscle (anterior byssus retractor of Mytilus) the intensity of the second layer line is preferentially increased. The indications are, therefore, that there may be similar changes in the actin filaments of all different kinds of muscles on activation.

The Aarhus group have also observed that in X-ray patterns from vertebrate striated muscle in rigor there is an increase in the intensity of the second actin layer line, and that this occurs irrespective of the degree of overlap of the actin and myosin filaments.

Vibert et al. conclude that the actin filaments can exist in two different configurations, one corresponding to a resting state, and the other to an activated state, and that the change from one to the other is not dependent on the presence of myosin. 